2. Verchot, L. V. et al., Climate changes: linking adaptation and mitigation through agroforestry. Mitig. Adapt. Strat. Gl. Change, 2007, 12, 901-910.

3. Koohafkan, P., Altieri, A. M. and Gimenez, H. E., Green Agriculture: foundations for biodiverse, resilient and productive agricultural systems. Int. J. Agric. Sustain., 2012, 10, 61-75.

4. Dhyani, S. K., Ram, A. and Dev, I., Potential of agroforestry systems in carbon sequestration in India. Indian J. Agric. Sci., 2016, 86, 1103-1112.

5. Kaul, M., Mohren, G. M. J. and Dadhwal, V. K., Carbon storage and sequestration potential of selected tree species in India. Mitig. Adapt. Strat. Gl. Change, 2010, 15, 489-510.

6. Shanker, A. K., Newaj, R., Rai, P., Solanki, K. R., Kareemulla, K., Tiwari, R. and Ajit, Microclimate modifications, growth and yield of intercrops under Hardwickia binata Roxb. based agroforestry system. Arch. Agron. Soil Sci., 2005, 51, 253-268.

7. Singh, G. and Rathod, T. R., Tree and crop growth and soil resource availability in Hardwickia binata Roxb agroforestry systems in the Indian desert. Arid Land Res. Manage., 2007, 21, 193210 .

8. Newaj, R., Chavan, S. B., Alam, B. and Dhyani, S. K., Biomass and carbon storage in trees grown under different agroforestry systems in semi-arid region of Central India. Indian Forester, 2016, 142, 642-648.

9. Rai, P., Solanki, K. R. and Singh, U. P., Growth and biomass production of multipurpose tree species in natural grass land under semi-arid condition. Indian J. Agroforest., 2000, 2, 101-103.

10. Misra, K. K., Rai, P. N. and Jaiswal, H. R., Effect of spacing and plant density on the growth of poplar (Populus deltoides Bartr. Ex Marsh). Indian Forester, 1996, 122, 65-68.

11. Silva, P. S. L. et al., Biomass of tree species as a response to planting density and interspecific competition. Revista Árvore, 2014, 38, 319-329.

12. Singh, G., Mutha, S. and Bala, N., Effect of tree density on productivity of a Prosopis cineraria agroforestry system in North Western India. J. Arid Environ., 2007, 70, 152-163.

13. Chave, J. et al., Improved allometric models to estimate the aboveground biomass of tropical trees. Global Change Biol., 2014, 20, 3177-3190.

14. Singh, G. and Singh, B., Rooting pattern and equations for estimating biomasses of Hardwickia binata and Colophospermum mopane trees in agroforestry system in Indian desert. Research and reviews. J. Bot. Sci., 2015, 4, 30-40.

15. Walkley, A. and Black, I. A., An examination of the Degtjareff method for determining soil organic matter, and proposed modification of the chromic acid titration method. Soil Sci., 1934, 37, 29-38.

16. Black, C. A., Methods of Soil Analysis Part 1, American Society of Agronomy, Madison, Wisconsin, USA, 1965.

17. Dhyani, A. S. K. et al., Estimating carbon sequestration potential of existing agroforestry systems in India. Agroforest. Syst., 2017, 91, 1101-1118.

18. Mangalassery, S., Dayal, D., Meena, S. L. and Ram, B., Carbon sequestration in agroforestry and pasture systems in arid north western India. Curr. Sci., 2014, 107(8), 1290-1293.

19. Saha, S. K., Nair, P. K. R., Nair, V. D. and Kumar, B. M., Soil carbon stock in relation to plant diversity of homegardens in Kerala, India. Agroforest. Syst., 2009, 76, 53-65.

20. Beckert, M. R., Smith, P., Lilly, A. and Chapman, S. J., Soil and tree biomass carbon sequestration potential of silvopastoral and woodland-pasture systems in North East Scotland. Agroforest. Syst., 2016, 90, 371-383.

21. Mansor, P. R., Vieira, H. D., Rangel, O. J. P., Partelli, F. L. and Gravina, G. A., Chemistry, nitrogen and carbon stocks in different land-use systems in a tropical environment. Afr. J. Agric. Res., 10(7), 660-667.

22. Sharma, G., Sharma, R. and Sharma, E., Impact of stand age on soil $\mathrm{C}, \mathrm{N}$ and $\mathrm{P}$ dynamics in a 40 -year chronosequence of alder- cardamom agroforestry stands of the Sikkim Himalaya. Pedobiologia, 2009, 52, 401-414.

23. Shreenivas, B. V., Hebbara, M., Yeledhalli, N. A. and Ravi, M. V., Long-term effects of trees on soil properties in the saltaffected vertisol. J. Indian Soc. Soil Sci., 2010, 58, 413-417.

24. Lenka, N. K., Dass, A., Susama, S. and Patnaik, U. S., Soil carbon sequestration and erosion control potential of hedgerows and grass filter strips in sloping agricultural lands of eastern India. Agric. Ecosyst. Environ., 2012, 158, 31-40.

25. Paul, K. I., Polglase, P. J., Nyakuengama, J. G. and Khanna, P. K., Change in soil carbon following afforestation. For. Ecol. Manage., 2002, 168, 241-257.

ACKNOWLEDGEMENTS. This work was supported by a network project 'National Innovations on Climate Resilient Agriculture (NICRA)' of the Indian Council of Agricultural Research (ICAR), New Delhi.

Received 20 December 2017; revised accepted 30 August 2018

doi: $10.18520 / \mathrm{cs} / \mathrm{v} 116 / \mathrm{i} 1 / 112-116$

\section{Myco-potash solubilizers}

\author{
B. K. Parida ${ }^{1}$, R. V. Vyas ${ }^{2, *}$, Y. K. Jhala ${ }^{2}$ and \\ S. Dasgupta ${ }^{1}$ \\ ${ }^{1}$ Bhagwan Mahavir College of M Sc Biotechnology, \\ Surat 395 017, India \\ ${ }^{2}$ Department of Agricultural Microbiology, Anand Agricultural \\ University, Anand 388 110, India
}

This study was carried out to evaluate the efficacy of agriculturally beneficial fungi for potash solubilization and to develop myco-potash cultures for use in crop growth. In all six fungal cultures were utilized in the study, viz. Paecilomyces lilacinus, Tricoderma harzianum, Aspergillus wentii, Emericella nidulans, Verticillium lecanii and Tricoderma viride. Among them, $A$. wentii and $T$. viride were found to produce 3.3 and $3.65 \mathrm{~mm}$ solubilization index around the colony after 7 days of incubation (DAI) on Aleksandrov medium supplemented with mica as potash source. Whereas for agar medium supplemented with feldspar, maximum solubilization index was $2.5 \mathrm{~mm}$ (A. wentii), $2.55 \mathrm{~mm}$ (T. viride), $2.48 \mathrm{~mm}$ (V. lecanii) and $2.58 \mathrm{~mm}$ (P. lilacinus) 7 DAI. To reveal the mechanism of potash solubilization, $A$. wentii, $T$. viride, $T$. harzianum and $V$. lecanii were chosen for organic acid profiling using HPCL. $A$. wentii produced the highest amount of total organic acid $(1847.775 \mu \mathrm{g} / \mathrm{ml})$.

Keywords: Fungal cultures, myco-potash, organic acids, solubilization index.

*For correspondence. (e-mail: rajababuvyas@gmail.com) 
PotAssium $(\mathrm{K})$ is one of 17 nutrients that are essential for plant growth. With the rapid development of agriculture in the world, available soil $\mathrm{K}$ levels have dropped due to crop removal, leaching, run-off and erosion. It thus becomes necessary to study the bio-activation of soil $\mathrm{K}$ reserves so as to alleviate the potash fertilizer shortage. Total soil $\mathrm{K}$ reserves are generally large, although the distribution of $\mathrm{K}$ forms differs from soil to soil as a function of the dominant soil minerals present ${ }^{1}$. Though potassium is present as an abundant element in the soil or is applied to the fields as natural or synthetic fertilizers only $1-2 \%$ of this is available to plants, the rest making complex with other minerals. The most common soil components of potassium, 90-98\%, are feldspar and mica. For optimal nutrition of a crop, replenishment of a K-depleted soil solution is necessary which in turn is affected predominantly by the release of exchangeable $\mathrm{K}$ from clay minerals. Consequently, for maximal crop growth, soil solution and exchangeable $\mathrm{K}$ need to be replenished continually with $\mathrm{K}$ through release by weathering of $\mathrm{K}$ reserves (i.e. mica and feldspars) ${ }^{2}$, or addition of $\mathrm{K}$ fertilizers. Many microorganisms in the soil are able to solubilize 'unavailable' forms of K-bearing minerals such as mica, illite and orthoclasses, by excreting organic acids which either directly dissolve rock $\mathrm{K}$ or chelate silicon ions to bring $\mathrm{K}$ into solution ${ }^{3-6}$. Therefore, application of $\mathrm{K}$-solubilizing microorganisms $(\mathrm{KSM})^{7-9}$ is a promising approach for increasing $\mathrm{K}$ availability in KSM amended soils. Production of carboxylic acids like citric, tartaric and oxalic acids was associated with potash solubilization by microorganisms. A wide range of bacteria namely Pseudomonas, Burkholderia, Enterobacter, Acidothiobacillus ferrooxidans, Bacillus mucilaginosus and Paenibacillus sp. Frateuria, Citrobacter, etc. and some fungi strains are known such as Aspergillus terreus (KSF-1), $T$. viride, etc. has been reported to release potassium in accessible form from potassium-bearing minerals in soil ${ }^{10-13}$. Agriculturally beneficial fungi play a major role as biodegrader and biocontrol agent, but meagre efforts have been made till date to exploit fungi as biofertilizers.

Keeping in mind the above mentioned facts and needs, in the present study we have evaluated the potash-solubilizing efficiency and possible mechanism of potash solubilization of known biocontol fungi, viz. T. harzianum, $T$. viride, $P$. lilacinus and $V$. lecanii having phosphate solubilization capacity ${ }^{14}$ and biodegrader fungi, viz. A. wentii and E. nidulan ${ }^{15,16}$ to develop myco-potash cultures. The aim of the present study was to put a stepping stone to explore role of biocontrol and biodegrader fungi as biofertilizers.

Fungal strains, viz. T. harzianum, T. viride, P. lilacinus and $V$. lecanii as well as biodegrader fungi, viz. A. wentii and $E$. nidulan ${ }^{15,16}$ were collected from culture depository of the Department of Agricultural Microbiology, B. A. College of Agriculture, Anand Agricultural Universty, Anand, Gujarat, India.
Individual fungal cultures were spot inoculated on Aleksandrov agar ${ }^{17}$ supplemented with natural substrate of potash, viz. mica or feldspar@2 g/l. Plates were incubated at $28^{\circ} \pm 2^{\circ} \mathrm{C}$ for seven days. Zone of clearance was checked around the fungal colonies at $48 \mathrm{~h}$ intervals. The zone of solubilization was measured and solubilization index was calculated, according to the ratio of total diameter (colony diameter + halo zone diameter) to the colony diameter.

\section{Solubilization index (SI)}

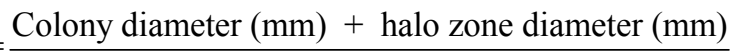
Colony diameter $(\mathrm{mm})$

Erlenmeyer flasks $(250 \mathrm{ml})$ containing $150 \mathrm{ml}$ Aleksandrov medium supplemented with feldspar or mica (i.e. six flasks for each) were autoclaved at $121^{\circ} \mathrm{C}$ for $20 \mathrm{~min}$. Sterilized media was inoculated with the respective fungal culture $\left(10^{8}\right.$ spores $\left./ \mathrm{ml}\right)$. For each test fungal culture, three flask were inoculated. The uninoculated flasks were treated as 'control'. Further the test samples were checked for potash release using flame photometry. One millilitre of sample was diluted with distilled water (1:9), mixed thoroughly and subjected to flame photometry for estimating and evaluating $\mathrm{K}$ content in the sample $^{18}$. The amount of the free potash released by the respective test fungi culture was recorded.

Organic acid qualitative and quantitative analysis ${ }^{19}$ was performed using high performance liquid chromatography (HPLC) technique ${ }^{10}$.

Potash solubilization efficiency of the fungal cultures was tested on Alekzendrov medium containing mica and feldspar as the source of mineral potash. The standard SI and zone size for potash solubilization is to be minimum $5 \mathrm{~mm}$ as per Fertilizer Control Order, Government of India (2014). The highest SI in Aleksandrov medium supplemented with mica was recorded for test culture T. viride (3.65). This was then followed by test cultures A. wentii (3.3) and E. nidulans (2.25) (Table 1). The test cultures $V$. lecanii, $T$. harzianum and $P$. lilacinus were not able to form any zone on the respective plates. As a result, they were able to solubilize the mineral potash, i.e. mica.

SI of the test culture on feldspar ranged from 2.45 to 2.58. The highest SI in Aleksandrov medium supplemented with feldspar was recorded for test culture P. lilacinus (2.58) followed by T. viride (2.55), A. wentii (2.5), E. nidulans (2.45) (Table 1). The test cultures $E$. nidulans and $T$. harzianum were not able to form any zone around the growth on the respective plates.

Studies on agar plates revealed that the clear zones formed by potash solubilizing microorganisms are due to the production of organic acids in the surrounding medium. However, it has previously been reported that most of the potash-solubilizing micro-organisms lose their 
Table 1. Solubilization index of fungal strains on Aleksandrov agar plate supplemented with mica

\begin{tabular}{|c|c|c|c|c|c|c|}
\hline \multirow[b]{2}{*}{ Organism } & \multicolumn{3}{|c|}{ Aleksandrov medium with mica } & \multicolumn{3}{|c|}{ Aleksandrov medium with feldspar } \\
\hline & $\begin{array}{c}\text { Colony } \\
\text { diameter }(\mathrm{mm})\end{array}$ & $\begin{array}{l}\text { Halo zone } \\
(\mathrm{mm})\end{array}$ & SI & $\begin{array}{c}\text { Colony } \\
\text { diameter }(\mathrm{mm})\end{array}$ & $\begin{array}{l}\text { Halo zone } \\
\text { (mm) }\end{array}$ & SI \\
\hline Aspergillus wentii & 1 & 2.3 & 3.3 & 2 & 3 & 2.5 \\
\hline Tricoderma viride & 2.2 & 3.2 & 3.65 & 2 & 3.1 & 2.55 \\
\hline Emericella nidulans & 1.2 & 1.5 & 2.25 & 1.2 & 1.5 & 2.45 \\
\hline Verticillium lecanii & 1.9 & 0 & 0 & 1.6 & 0 & 0 \\
\hline Tricoderma harzianum & 1.7 & 0 & 0 & 1.9 & 0 & 0 \\
\hline Paecilomyces lilacinus & 1.4 & 0 & 0 & 1.2 & 1.9 & 2.58 \\
\hline
\end{tabular}

ability to form halo zone on the medium due to repeated sub-culturing. Generally, potash-solubilizing microorganisms are routinely screened based on SI. However, the reliability of this halo-based technique is being questioned as many isolates which do not produce any visible halo zone on agar plates could still solubilize various types of insoluble inorganic potash in liquid medium. A wide range of bacteria, namely Pseudomonas, Burkholderia, Enterobacter, Acidothiobacillus ferrooxidans, Bacillus mucilaginosus, Paenibacillus sp., Frateuria, Citrobacter, etc. and fungi strains such as A. terreus (KSF-1), $T$. viride, etc. have been reported to release potassium in accessible form from potassium-bearing minerals in soil $^{11,12,20,21}$.

After observing the positive SI of potential potashsolubilizing fungi on Aleksandrov agar plates supplemented with mica and feldspar respectively, the test cultures were further analysed in Aleksandrov liquid medium for $\mathrm{K}$ release from minerals feldspar and mica from 2 to 10 days of incubation (DAI).

In Aleksandrov medium supplemented with feldspar (Table 2), fungal strain $A$. wentii gave highest $\mathrm{K}$ release $\left(3.7 \mu \mathrm{g} \mathrm{ml}^{-1}\right)$ at $10 \mathrm{DAI}$, which was found to be increasing from the second to the tenth day. It was considered as the best $\mathrm{K}$ solubilizer. Next was $T$. viride, which showed $2.9 \mu \mathrm{g} \mathrm{ml}^{-1}$ of $\mathrm{K}$ release at $10 \mathrm{DAI}$, viz. $V$. lecanii showed $1.8 \mu \mathrm{g} \mathrm{ml}^{-1}$ of $\mathrm{K}$ release at $10 \mathrm{DAI}$ and $P$. lilacinus showed equal rate of solubilization, i.e. $1.1 \mu \mathrm{g} \mathrm{ml}^{-1}$. Least $\mathrm{K}$ release was exhibited by $T$. harzianum which gave $0.75 \mu \mathrm{g} \mathrm{ml}^{-1}$ at $10 \mathrm{DAI}$ and solubilization was actually observed at 8 DAI.

Similarly, for Aleksandrov medium supplemented with mica, the test cultures were further analysed for $\mathrm{K}$ release with broth in the presence of mica from 2 to $10 \mathrm{DAI}$. Fungal strain $A$. wentii gave highest $\mathrm{K}$ release $\left(2.5 \mu \mathrm{g} \mathrm{ml}^{-1}\right)$ at $10 \mathrm{DAI}$, which was found to be increasing from the second to tenth day. It was considered as the best $\mathrm{K}$ solubilizer. Next was $T$. viride, which showed $2.9 \mu \mathrm{g} \mathrm{ml}^{-1}$ of $\mathrm{K}$ release at $10 \mathrm{DAI}, V$. lecanii and $E$. nidulans showed equal $\left(0.75 \mu \mathrm{g} \mathrm{ml}^{-1}\right) \mathrm{K}$ release at $10 \mathrm{DAI}$. P. lilacinus and $T$. harzianum showed, i.e. 1.4 and $1.1 \mu \mathrm{g} \mathrm{ml}^{-1}$ respectively. Least $\mathrm{K}$ release was exhibited by $T$. harzianum $\left(0.75 \mu \mathrm{g} \mathrm{ml}^{-1}\right)$ at $10 \mathrm{DAI}$ and solubilization was actually observed at 8 DAI.
Some fungal strains are able to solubilize rock potassium and potassium aluminum silicate. Isolates of Aspergillus were selected from ceramic industry soils which showed high solubilization of potassium aluminum silicate. $A$. terreus showed more solubilization when grown in the presence of $1 \%$ rock potassium (feldspar) than $A$. niger ${ }^{13}$. Similarly, K release from muscovite mica by all isolates increased with increase in incubation time; it was maximum at 20 DAI ranging from 2.41 to $44.49 \mu \mathrm{g} / \mathrm{ml}$. KSB11 released maximum amount of $\mathrm{K}$ from mica followed by KSB42, which gave $37.07 \mu \mathrm{g} / \mathrm{ml}$. Out of the 30 isolates, 9 showed more than $20 \mu \mathrm{g} / \mathrm{ml}$ solubilization. Similarly, isolate MCRCp1 could solubilize a significant amount of $\mathrm{K}$ from muscovite mica $\left(4.29 \mathrm{mg} \mathrm{l}^{-1}\right.$ ) than other potassium containing minerals like microcline $\left(1.26 \mathrm{mg}^{-1}\right)$ and orthoclase $\left(0.85 \mathrm{mg} \mathrm{l}^{-1}\right)^{1,22}$.

Results of the experiment to the evaluate role of yeast Torulaspora globosa, isolated from the sugar cane rhizosphere, in the solubilization of potassium from alkaline ultramafic rock powder showed that as much as $38 \%$ of the total potassium in the rocks was released in the medium with yeast during a 15-day period of incubation. Acid production may be the mechanism by which yeast solubilizes potassium, because the total acidity increased during the sampling period ${ }^{23}$.

Very few reports are available on optimization of potassium solubilizatiion by heterotrophic microorganisms. The results obtained from a study regarding ${ }^{24}$, the optimization of feldspar solubilzation, 25 isolates were obtained from the rhizospheric soil of seasonal plants and ceramic industrial soil. Among 25 isolates, Aspergillus SDS7 was studied for optimum conditions for maximum solubilization of $\mathrm{K}$. The amount of $\mathrm{K}$ released by the isolates ranged from 4.5 to $52.16 \mathrm{ppm}$. It was seen that $\mathrm{pH}$ 6.0 was the best for $\mathrm{K}$ solubilization and citric acid production, $25.16 \mathrm{ppm}$ and $45.55 \mathrm{ppm}$ respectively.

Organic matter after decomposition produces acids like citiric acid, formic acid, malic acid, oxalic acid. These organic acids enhance the dissolution of potassium compounds by supplying protons and by complexing $\mathrm{Ca}^{2+}$ ions. Previous work has shown organic compounds produced by microorganisms such as acetate, citrate and oxalate can increase mineral dissolution in soil ${ }^{25}$. Solubilization of potassium occurs by complex formation 
RESEARCH COMMUNICATIONS

Table 2. K release from feldspar and mica (potash mineral) in Aleksandrov broth

\begin{tabular}{|c|c|c|c|c|c|c|c|c|c|c|}
\hline \multirow[b]{2}{*}{ Organism } & \multicolumn{5}{|c|}{ Aleksandrov medium with feldspar $(\mu \mathrm{g} / \mathrm{ml})$} & \multicolumn{5}{|c|}{ Aleksandrov medium with mica $(\mu \mathrm{g} / \mathrm{ml})$} \\
\hline & 2 DAI & 4 DAI & $6 \mathrm{DAI}$ & $8 \mathrm{DAI}$ & $10 \mathrm{DAI}$ & 2 DAI & 4 DAI & $6 \mathrm{DAI}$ & 8 DAI & $10 \mathrm{DAI}$ \\
\hline T. viride & 0.75 & 1.4 & 1.8 & 2.2 & 2.9 & 0.75 & 1.1 & 1.1 & 1.4 & 1.8 \\
\hline$V$. lecanii & 0.4 & 0.4 & 0.75 & 1.1 & 1.8 & 0 & 0 & 0.4 & 0.4 & 0.75 \\
\hline E. nidulans & 0 & 0.4 & 0.75 & 0.75 & 1.1 & 0 & 0.4 & 0 & 0.4 & 0.75 \\
\hline P. lilacinus & 0.4 & 0.4 & 0.75 & 1.1 & 1.1 & 0.4 & 0.4 & 1.1 & 1.1 & 1.4 \\
\hline
\end{tabular}

DAI, Days after incubation.

Table 3. Organic acid profile of promising potassium solubilizing test fungal cultures by HPLC at 7 days after inoculation

\begin{tabular}{|c|c|c|c|c|}
\hline \multirow[b]{2}{*}{ Organic acid } & \multicolumn{4}{|c|}{ Organic acid production by fungal strains $(\mu \mathrm{g} / \mathrm{ml})$} \\
\hline & M 5 (T. harzianum) & M 7 (V. lecani) & M 9 (T. viride) & M 11 (A. wentii) \\
\hline Oxalic acid & 136.45 & 131.20 & 88.30 & 104.75 \\
\hline Gluconic acid & 0.0 & 0.0 & 0.0 & 0.0 \\
\hline Tartaric acid & 0.0 & 0.0 & 0.0 & 0.0 \\
\hline Pyruvic acid & 0.0 & 0.0 & 0.0 & 0.0 \\
\hline Malic acid & 0.0 & 0.0 & 0.0 & 0.0 \\
\hline Malonic acid & 0.0 & 0.0 & 0.0 & 0.0 \\
\hline Lactic acid & 275.10 & 0.0 & 68.46 & 1620.45 \\
\hline Acetic acid & 68.58 & 66.15 & 0.0 & 122.58 \\
\hline Citric acid & 0.0 & 0.0 & 0.0 & 0.0 \\
\hline 2-Keto gluconic acid & 0.0 & 0.0 & 0.0 & 0.0 \\
\hline Propionic acid & 0.0 & 0.0 & 0.0 & 0.0 \\
\hline Butaric acid & 0.0 & 0.0 & 0.0 & 0.0 \\
\hline Succinic acid & 0.0 & 0.0 & 0.0 & 0.0 \\
\hline Total & 480.1301 & 197.3548 & 156.76 & 1847.775 \\
\hline
\end{tabular}

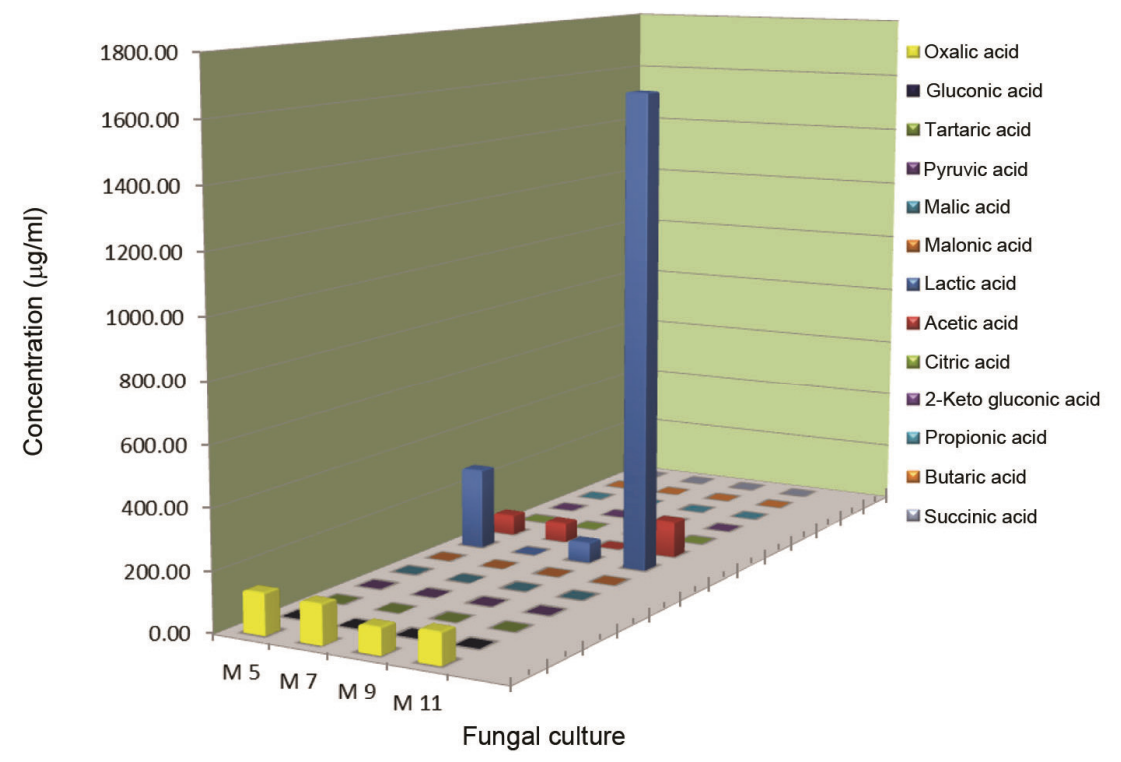

Figure 1. Organic acid production profile of selected test fungal cultures.

between organic acids and metal ions such as $\mathrm{Fe}^{2+}, \mathrm{Al}^{3+}$ and $\mathrm{Ca}^{2+}$ (ref. 26).

HPLC analysis of culture filtrate was carried out to identify and quantify the organic acids produced during solubilization of mineral potash by $A$. wentii, T. viride, $T$. harzianum and $V$. lecanii at 7 DAI. During feldspar solubilization, it was found that the major organic acids produced by all the four fungi are lactic acid, acetic acid 


\section{RESEARCH COMMUNICATIONS}

and oxalic acid. It was observed that $A$. wentii produced maximum amount of lactic acid $(1620.45 \mu \mathrm{g} / \mathrm{ml})$ followed by acetic acid $(122.58 \mu \mathrm{g} / \mathrm{ml})$ and oxalic acid $(104.75 \mu \mathrm{g} / \mathrm{ml})$ at 7 DAI (Table 3$)$. Test fungi $T$. viride showed organic acid production with major share of oxalic acid $(88.30 \mu \mathrm{g} / \mathrm{ml})$ and lactic acid $(68.46 \mu \mathrm{g} / \mathrm{ml})$. Table 3 shows organic acids which are produced in lower and higher concentration.

Total organic acid production was recorded as 1847.775 and $480.1301 \mu \mathrm{g} / \mathrm{ml}$ by $A$. wentii and $T$. harzianum respectively; $T$. viride and $V$. lecanii showed comparatively less overall organic acids production (197.3548 and $156.76 \mu \mathrm{g} / \mathrm{ml}$ respectively). Overall results show that lactic acid is the major organic acid produced by both the isolates followed by acetic acid and oxalic acid (Figure 1).

It has earlier been reported that potassium soluiblizing bacteria $B$. mucilaginosus are able to solubilize rock $\mathrm{K}$ mineral powder such as mica, illite and orthoclase through production and excretion of organic acids ${ }^{5}$. The weathering ability of bacteria involves production of protons, organic acids, siderophores and organic ligands. This was observed in Cladosporoides, Cladosporium and Pencillium sp. These fungal species isolated have the capacity to produce large amounts of oxalic, citric and gluconic acids in broth culture that leads to deterioration of clay silicates, mica and feldspar, and filamentous fungi can cause extensive weathering of stone due to organic acid excretion $^{27}$.

1. Sugumaran, P. and Janartham, B., Solubilization of potassium minerals by bacteria and their effect on plant growth. World $J$ Agric. Sci., 2007, 3(3), 350-355.

2. Sparks, D. L. and Huang, P. M., Physical chemistry of soil potassium. In Potassium in Agriculture (ed. Munson, R. D.), American Society of Agronomy, Madison, WI, USA, 1985, pp. 202-276.

3. Groudev, S. N., Use of heterotrophic micro-organisms in mineral biotechnology. Acta Biotechnol., 1987, 7, 299-306.

4. Friedrich, S., Platonova, N. P., Karavaiko, G. I., Stichel, E. and Glombitza, F., Chemical and microbiological solubilization of silicates. Acta Biotechnol., 1991, 11, 187-196.

5. Ullaman, W. J., Kirchman, D. L. and Welch, S. A., Laboratory evidence for microbially mediated silicate mineral dissolution in nature. Chem. Geol., 1996, 132, 11-17.

6. Bennett, P. C., Choi, W. J. and Rogera, J. R., Microbial destruction of feldspars. Miner. Manage., 1998, 8(62A), 149-150.

7. Zahra, M. K., Monib, M. S., Abdel-A1, I. and Heggo, A., Significance of soil inoculation with silicate bacteria. Zentralbf Mikrobiol., 1984, 139(5), 349-357.

8. Vandevivere, P., Welch, S. A., Ullman, W. J. and Kirchman, D. L., Enhanced dissolution of silicate minerals by bacteria at nearneutral pH. Microb. Ecol., 1994, 27, 241-251.

9. Argelis, D. T., Gonzala, D. A., Vizcaino, C. and Gartia, M. T., Biochemical mechanism of stone alteration carried out by filamentous fungi living in monuments. Biogeochemistry, 1993, 19, $129-147$.

10. Vyas, P. and Gulati, A., Organic acid production in vitro and plant growth promotion in maize under controlled environment by phosphate-solubilizing fluorescent Pseudomonas. BMC Microbiol., 2009, 9(174), 1-15.
11. Lian, B., Fu, P. Q., Mo, D. M. and Liu, C. Q., A comprehensive review of the mechanism of potassium release by silicate bacteria. Acta Mineral. Sin., 2002, 22, 179-183.

12. Liu, D., Lian, B. and Dong, H., Isolation of Paenibacillus sp. and assessment of its potential for enhancing mineral weathering. Geomicrobiol. J., 2012, 29, 413-421.

13. Prajapati, K., Sharma, M. C. and Modi, H. A., Growth promoting effect of potassium solubilizing microorganisms on Okra (Abelmoscus esculantus). Int. J. Agric. Sci. Res., 2013, 3(1), 181-188.

14. Shukla, R. M. and Vyas, R. V., Phosphate solubilizing activity of mycopesticides. Int. J. Agric. Environ. Biotechnol., 2014, 7(4), 705-710.

15. Kushwaha, P., Vyas, R. V., Jhala, Y. K. and Patel, H. K., Diversity of plastic degrading microorganisms and their appraisal on biodegradable plastic. Appl. Ecol. Environ. Res., 2013, 11(3), $441-449$.

16. Dabhi, B. K., Jhala, Y. K., Vyas, R. V. and Shelat, H. N., Bacterial and fungal biodegraders consortia for effective decomposition of wheat straw to obtain nutritive organic compost. J. Pure Appl. Microbiol., 2014, 8(6), 4793-4801.

17. Aleksandrov, V. G., Blagodyr, R. N. and Ivies, I. P., Liberation of phosphoric acid from apatite by silicate bacteria. Microbiol. $\mathrm{Zh}$. (Kiev), 1967, 29, 111-114.

18. Hu, X. F., Chen, J. and Guo, J. F., Two phosphate- and potassiumsolubilizing bacteria isolated from Tianmu Mountain, Zhejiang, China. World J. Microbiol. Biotechnol., 2006, 22, 983-990.

19. Dinkci, N., Akalın, A. S., Gönc, S. and Unal, G., Isocratic reversephase HPLC for determination of organic acids in Karg1 Tulum cheese. Chromatographia, 2007, 66, 45-49.

20. Sheng, X. F., Growth promotion and increased potassium uptake of cotton and rape by a potassium releasing strain of Bacillus edaphicus. Soil Biol. Biochem., 2005, 37, 1918-1922.

21. Li, F. C., Li, S., Yang, Y. Z. and Cheng, L. J., Advances in the study of weathering products of primary silicate minerals, exemplified by mica and feldspar. Acta Petrol. Mineral., 2006, 25, 440448.

22. Archana, D. S., Nandish, M. S., Savalagi, V. P. and Alagawadi, A. R., Characterization of potassium solubilizing bacteria (KSB) from rhizosphere soil. Bioinfolet, 2013, 10, 248-257.

23. Rosa-Magri, M. M., Avansini, S. H., Lopes-Assad, M. L., TaukTornisielo, S. M. and Ceccato-Antonini, S. R., Release of potassium from rock powder by the yeast Torulaspora globosa. Braz. Arch. Biol. Technol., 2012, 55(4), 577-582.

24. Qureshi, S. A., Qureshi, R. A., Tipre, D. R. and Dave, S. R., Dissolution of potassium from silicate mineral by Aspergillus strain. Int. Res. J. Environ. Sci., 2016, 5(2), 63-66.

25. Sheng, X. F., Xia, J. J. and Chen, J., Mutagenesis of the Bacillus edphicaus strain NBT and its effect on growth of chili and cotton. Agric. Sci. China, 2003, 2, 40-41.

26. Styriakova, I., Styriak, I., Hradil, D. and Bezdicka, P., The release of iron bearing minerals and dissolution of feldspar by heterophic bacteria of Bacillus species. Ceram. Silikaty, 2003, 47(1), 20-26.

27. Argelis, D. T., Gonzala, D. A., Vizcaino, C. and Gartia, M. T., Biochemical mechanism of stone alteration carried out by filamentous fungi living in monuments. Biogeochemistry, 1993, 19, 129-147.

Received 5 September 2015; revised accepted 26 August 2018

doi: $10.18520 / \mathrm{cs} / \mathrm{v} 116 / \mathrm{i} 1 / 116-120$ 